\title{
Poem and Original Art
}

Thoai Q. Tran

Thomas Jefferson University

Follow this and additional works at: https://jdc.jefferson.edu/tmf

Let us know how access to this document benefits you

\section{Recommended Citation}

Tran, Thoai Q. (2001) "Poem and Original Art," The Medicine Forum: Vol. 3 , Article 11.

DOI: https://doi.org/10.29046/TMF.003.011

Available at: https://jdc.jefferson.edu/tmf/vol3/iss1/11

This Article is brought to you for free and open access by the Jefferson Digital Commons. The Jefferson Digital Commons is a service of Thomas Jefferson University's Center for Teaching and Learning (CTL). The Commons is a showcase for Jefferson books and journals, peer-reviewed scholarly publications, unique historical collections from the University archives, and teaching tools. The Jefferson Digital Commons allows researchers and interested readers anywhere in the world to learn about and keep up to date with Jefferson scholarship. This article has been accepted for inclusion in The Medicine Forum by an authorized administrator of the Jefferson Digital Commons. For more information, please contact: JeffersonDigitalCommons@jefferson.edu. 


\section{The Art of Medicine}

Thoai Tran, MD, Resident Department of Internal Medicine 1999-2002

The painting of the canvas does require creativity, a motivation fully inspired, to animate life from empty void of space worth a thousand words, if just a trace. To paint the mind with passion and ideas, Cultivating the heart with wisdom so clear, a true teacher brings colors to the soul into your heart all his lessons shall go, a memorized fact anybody can surely depart but teaching medicine is more like an art, With passion to blossom a developing mind and let it bloom, becoming one of a kind. such is the way of teachers to truly care, helping others when nobody else shall dare A healer of the soul in those tragic hours empathy and compassion; not an ivory tower of academic prestige, that research volume when to the patients he shall never come. Within the timeless art we now recognize our teachers who have richened our lives. Remember no single plaque can ever show our appreciation to those we will know: teachers, healers, colleagues, and friends let the art.

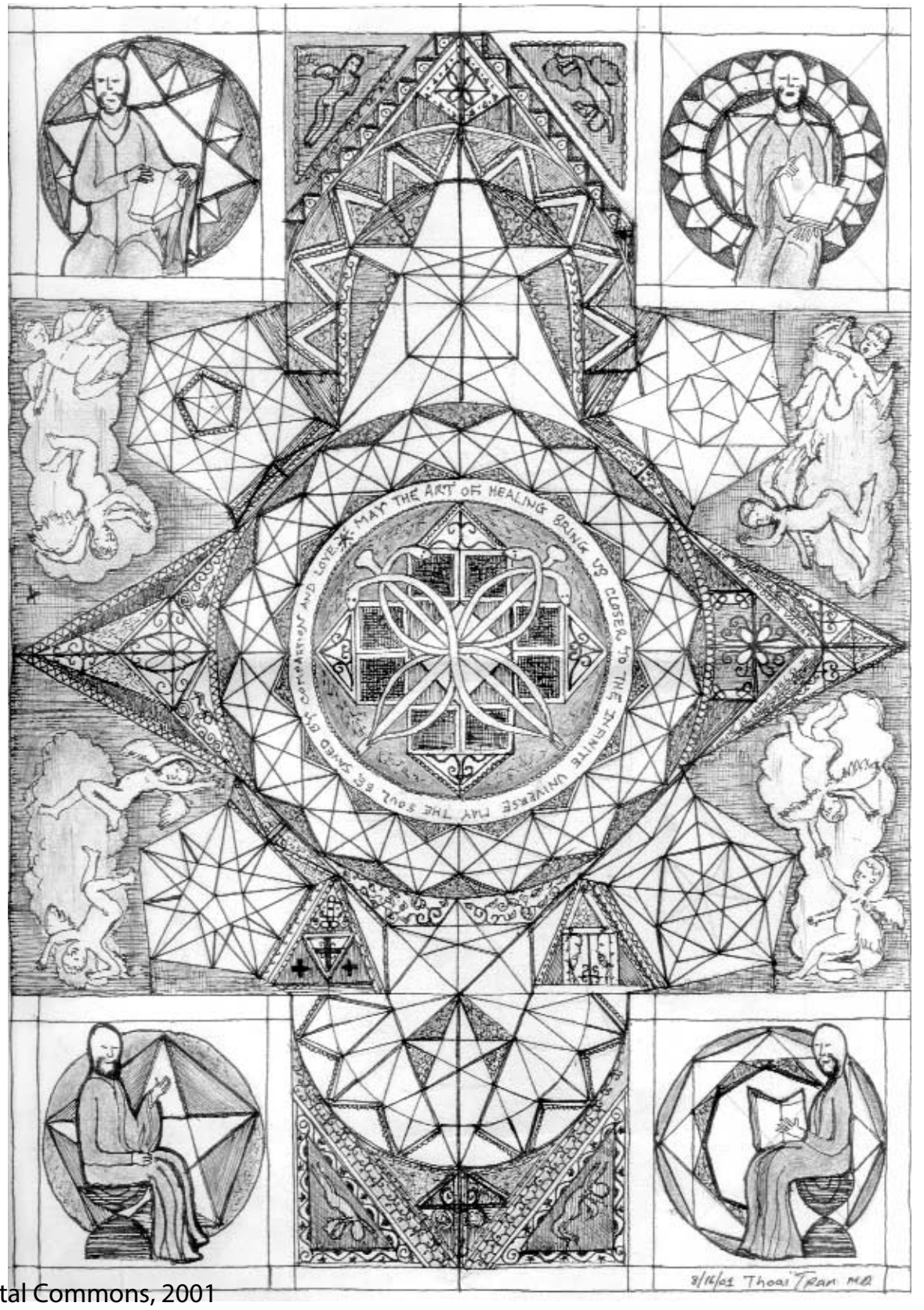

